\title{
Review: The Peruvian Empire
}

\section{Author(s): A. H. Keane}

Review by: A. H. Keane

Source: The Geographical Journal, Vol. 37, No. 4 (Apr., 1911), p. 439

Published by: geographicalj

Stable URL: http://www.jstor.org/stable/1778422

Accessed: 16-04-2016 11:03 UTC

Your use of the JSTOR archive indicates your acceptance of the Terms \& Conditions of Use, available at

http://about.jstor.org/terms

JSTOR is a not-for-profit service that helps scholars, researchers, and students discover, use, and build upon a wide range of content in a trusted digital archive. We use information technology and tools to increase productivity and facilitate new forms of scholarship. For more information about JSTOR, please contact support@jstor.org.

The Royal Geographical Society (with the Institute of British Geographers), Wiley are collaborating with JSTOR to digitize, preserve and extend access to The Geographical Journal 


\begin{abstract}
AMERICA.
The Peruvian Empire.

'The Incas of Peru.' By Sir Clements Markham, к.с.в. With sixteen illustrations and map. London: Smith, Elder. 1910.
\end{abstract}

For over fifty years the author of this learned and pleasantly written history of Peruvian culture has been almost uninterruptedly associated with HispanoAmerican affairs, and he may even claim to be a benefactor of mankind by his introduction of the quinine-yielding Chinchona plant into British India from this region. In the present work, which may be described as mainly historical, he has given us a well-digested account of the Peruvian Empire, taking this expression in the widest sense of the term. It thus includes nearly all that can now be known of the two pre-Inca States of Chimu on the west coast and of Tiahuanaco at the south end of Lake Titicaca. An opportunity is thus afforded of dealing with the mound-building Chimus, whose relations lay probably with the cultured peoples of the north (Mayas? Aztecs?), and with the megalithic builders of Aymaraland.

The account of the Incas proper is very full, and nothing better has been written on this subject since Prescott's 'Conquest of Peru,' of which the present work may be regarded as a complement. We have a vivid description of " the land of the Incas, the land of the sovereign city [Cuzco], the land of the sacred vale! The land converted from the home of many contending tribes, to a realm obedient to one king and lord. The land of the Incas was 250 miles in length by 60 in width. It was bounded on its western side by the river Apurimac, 'Chief of the speaking waters,' dashing down a profound ravine with precipitous sides. On the east was the Vilcamayu, 'the sacred river,' flowing from 'the sacred lake' at the foot of the lofty, snowy peak which is visible from Cuzco, rising majestically into the azure sky. Unlike the Apurimac, the Vilcamayu irrigates a wide and fertile valley unsurpassed for beauty in the wide world. To the south this classic land is separated from the basin of Lake Titicaca by the knot of Vilcañeta which connects the eastern and maritime Cordilleras. To the north the wild mountains of Vilcapampa finally sink down into the tropical Amazonian forests."

The sections devote 1 to the religion, feasts, customs, language, and literature - of the Quichuas, as the cultured Peruvians were and still are collectively called, are excellently treated, and special attention has been paid to the political and social condition of the people under the Inca administration. Those who are at present so zealuusly advocating certain communistic systems in Europe and America will here find that andlogous principles had already been adopted, and found wanting, by the pre-Columbian rulers of the Peruvian empire. Their subjects formed so many organized groups of which the family was the unit, and which collectively constituted a patriarchal system under the Inca government. There was, strictly speaking, no private property, and the arable land was only temporarily held by the heads of the Ayllus, as the several communities were called. Lack of space prevents a detailed account of this purely socialistic régime "such as dreamers in past ages have conceived, and unpractical theorists now talk about." It established peace throughout the land, and supplied the people with all their material wants, but brought them under an inexorable despotism which left them unmanned. Hence the whole system fell to pieces at th: first shock of the Conquistadores, "and the unequalled fabric disappeared for ever."

\title{
A. H. Keane.
}

